\title{
Survivability of Plant Growth-Promoting Microorganisms on Spent Mushroom Substrate
}

\author{
G. Dakshayini* and B.C. Mallesha \\ Department of Agricultural Microbiology, UAS, GKVK, Bengaluru - 560065 , \\ Karnataka, India \\ *Corresponding author
}

\begin{tabular}{|l|}
\hline Ke y w o r d s \\
$\begin{array}{l}\text { Pseudomonas } \\
\text { fluorescens, Bacillus } \\
\text { megaterium and } \\
\text { Trichoderma harzianum }\end{array}$ \\
\hline Article Info \\
\hline $\begin{array}{l}\text { Accepted: } \\
15 \text { October } 2018 \\
\text { Available Online: } \\
10 \text { November } 2018\end{array}$ \\
\hline
\end{tabular}

The present study was conducted at the Department of Agricultural Microbiology, GKVK, University of Agricultural Sciences, Bengaluru-65. Spent mushroom substrate obtained after the mushroom cultivation was rich in nutrients and it was used as carrier material for the survival studies of plant growth promoting microorganisms (Pseudomonas fluorescens, Bacillus megaterium and Trichoderma harzianum) at different time intervals by serial dilution plate count technique up to 120 days. At all the intervals of population studied, treatments which received inoculation of single organism showed higher population compared to the population in consortia which contained all the three plant growth promoting microorganisms (Pseudomonas fluorescens + Bacillus megaterium + Trichoderma harzianum). The survivability of plant growth promoting microorganisms on both oyster mushroom and milky spent substrates were on par each other. From the results of survivability studies it is confirmed that, spent mushroom substrate can be used as carrier material for plant growth promoting microorganisms. Among the different plant growth promoting microorganisms, Trichoderma harzianum showed better survivability.

\section{Introduction}

Plant growth promoting microorganisms are a group of microorganisms, which interact with plants and influences plant health and soil fertility. They play an important role in disease control and plant growth promotion.

Microbial consortia are group of different species of microorganisms that act together as a community. The microbial consortia are much more efficient than single strains of microorganisms with a diversity of metabolic capabilities and microorganisms interact with each other synergistically by providing nutrients and removing inhibitory products. Co-inoculation frequently increases growth and yield compared to single inoculation by providing the plant with balanced nutrition and mineral nutrients.

Mushrooms are spore bearing, fleshy fruiting bodies of the fungi, that are typically produced above ground soil (Chandulal et al., 2013; Sharma and Atri, 2014). They are widely consumed as vegetables and they are also reported as medical resource (Mortimer et al., 2012; Bandara et al., 2015). Spent Mycelium Substrate (SMS) is a valuable by-product of mushroom cultivation. It consists of partially 
degraded paddy or wheat straw, coconut husk, bagasse or other agricultural waste. After a few cultivation cycles, it is bio chemically modified by fungal enzymes into a simpler form and enriched with protein. Fresh and aged mushroom spent substrate has been applied to propagation of fruits, vegetables, flower and foliage crops (Robbins et al., 1986). It is a rich source of carbon, nitrogen and other elements. Nitrogen content varies from $0.4-13.7 \%$ and also contains cations like $\mathrm{K}^{+}, \mathrm{Na}^{+}, \mathrm{Ca}^{2+}$ and $\mathrm{Mg}^{2+}$, and anions like $\mathrm{Cl}^{-}$, $\mathrm{NO}_{3}{ }^{-}$and $\mathrm{SO}_{4}{ }^{2-}$, all essential for optimal plant growth development (Chorover et al., 2000), with this background present study was taken up to evaluate survivability of plant growth promoting microorganisms by using spent mushroom substrate as carrier material.

\section{Materials and Methods}

\section{Collection and multiplication of plant growth promoting microorganisms}

The Plant Growth Promoting Microorganisms selected were Pseudomonas fluorescens, Bacillus megaterium and Trichoderma harzianum. These microbial inoculants were obtained from the Department of Agricultural Microbiology, UAS, GKVK, Bengaluru.

A loop full pure culture of Pseudomonas fluorescens, Bacillus megaterium and Trichoderma harzianum were aseptically transferred to $250 \mathrm{ml}$ conical flasks containing $100 \mathrm{ml}$ of the Pikovskaya's broth, King's B broth and Potato dextrose broth respectively and incubated for 2-3 days at $28 \pm 2{ }^{\circ} \mathrm{C}$ to obtain maximum growth. Slant cultures maintained at $4{ }^{\circ} \mathrm{C}$ served as mother cultures

\section{Preparation of mushroom spent substrate}

After the mushroom cultivation the leftover byproduct mushroom spent substrate was collected, dried and used for further analysis.

\section{Chemical analysis of spent mushroom substrates}

Chemical analysis of mushroom spent substrates was carried out for total N, P, K and organic carbon content by adopting following methods.

Organic carbon (\%): Dry combustion method (Mikhailova et al., 2003)

Total nitrogen (\%): Micro Kjeldhal Method (Piper, 1966).

Total phosphorus (\%): Vanadomolybdate yellow color method (Jackson, 1973)

Total potassium (\%): Flame Photometer (Piper, 1966).

\section{$C: \mathrm{N}$ ratio of the substrates}

$\mathrm{C}: \mathrm{N}$ ratio of the substrates was calculated by taking total per cent organic carbon and total percent nitrogen values of substrates.

\section{Survivability of plant growth promoting microorganisms}

Survivability of plant growth promoting microorganisms such as Pseudomonas fluorescens, Bacillus megaterium, Trichoderma harzianum and their consortia was studied on the spent mushroom substrates by using it as carrier material.

Twenty five grams of mushroom spent substrate was taken in polythene bags and sterilized in an autoclave $121{ }^{\circ} \mathrm{C}$ for $15 \mathrm{~min}$ at $15 \mathrm{lbs}$ pressure.

After sterilization, substrates were brought to optimum temperature and moisture condition and then substrates were inoculated with 4 days old cultures of Pseudomonas fluorescens, Bacillus megaterium, Trichoderma harzianum 
and their consortia. The survivability of the microorganisms at different intervals such as 0, 30, 60 and 90 days after inoculation were determined by dilution plate count method using King's B, Pikovoskaya's and Trichoderma specific media for Pseudomonas fluorescens, Bacillus megaterium and Trichoderma harzianum respectively.

\section{Treatment details}

$\mathrm{T}_{1}$ - Oyster spent mushroom substrate + Pseudomonas fluorescens

$\mathrm{T}_{2}$ - Oyster spent mushroom substrate + Bacillus megaterium

$\mathrm{T}_{3}$ - Oyster spent mushroom substrate + Trichoderma harzianum

$\mathrm{T}_{4}$ - Oyster spent mushroom substrate + Consortia

$\mathrm{T}_{5}$ - Milky spent mushroom substrate + Pseudomonas fluorescens

$\mathrm{T}_{6}$ - Milky spent mushroom substrate + Bacillus megaterium

$\mathrm{T}_{7}$ - Milky spent mushroom substrate + Trichoderma harzianum

$\mathrm{T}_{8}-$ Milky spent mushroom substrate + Consortia

$\mathrm{T}_{9}-$ Talc + Pseudomonas fluorescens

$\mathrm{T}_{10}-$ Talc + Bacillus megaterium

$\mathrm{T}_{11}-$ Talc + Trichoderma harzianum

$\mathrm{T}_{12}-$ Talc + Consortia

Note: Consortia (Pseudomonas fluorescens + Bacillus megaterium + Trichoderma harzianum)

\section{Results and Discussion}

Spent mushroom substrates were enriched with plant growth promoting microorganisms and their survivability was studied at different time intervals by standard plate count technique. The results pertaining to survivability of plant growth promoting microorganisms in spent mushroom substrates are presented in Table 1.

\section{At 0 DAI}

The population recorded at different days intervals (30, 60, 90 and 120 DAI) were converted to per cent values by keeping initial values as hundred per cent base and data is presented in Table 2 and illustrated in Figure $1 \mathrm{a}, 1 \mathrm{~b}$ and $1 \mathrm{c}$.

\section{At 30 DAI}

At thirty days after inoculation, the population of plant growth promoting microorganisms varied significantly. Among different organisms inoculated, there was a reduction in the population of Pseudomonas fluorescens and Bacillus megaterium treated with spent mushroom substrates and they were same in case of talc. At the same time, the population Trichoderma harzianum was increased significantly in both talc and spent mushroom substrate. At 30 DAI maximum population was found in talc carrier material and with respect to different mushroom spent substrates used, the maximum population was observed on milky spent mushroom substrate compared to oyster SMS.

In case of single plant growth promoting microorganism inoculation, significantly maximum population was observed in $\mathrm{T}_{9}$ (Talc + Pseudomonas fluorescens) which recorded the population of $92 \times 10^{8} \mathrm{cfu} / \mathrm{g}$ followed by in Talc + Bacillus megaterium $\left(75 \times 10^{8} \mathrm{cfu} / \mathrm{g}\right)$. Among different spent 
mushroom substrates, significantly higher population of $55.66 \times 10^{6} \mathrm{cfu} / \mathrm{g}$ was observed by Pseudomonas fluorescens in milky SMS followed by Bacillus megaterium $\left(53.44 \times 10^{6}\right.$ cfu /g) on milky mushroom spent substrate which was on par with Pseudomonas fluorescens on oyster SMS $\left(52.78 \times 10^{6} \mathrm{cfu}\right.$ /g). Significantly lower population was observed by Trichoderma harzianum in both oyster $\left(36.89 \times 10^{6} \mathrm{cfu} / \mathrm{g}\right)$ and milky SMS $\left(37.67 \times 10^{6} \mathrm{cfu} / \mathrm{g}\right)$ and they were on par with each other.

In consortia, less population was observed by all organisms compared to single inoculation. In consortia, significantly the highest population was observed by Pseudomonas fluorescens treated with talc $\left(75 \times 10^{8} \mathrm{cfu} / \mathrm{g}\right)$ followed by in Talc + Bacillus megaterium $\left(66.33 \times 10^{8} \mathrm{cfu} / \mathrm{g}\right)$. Among the treatments which received spent mushroom substrate, maximum population was recorded by Trichoderma harzianum in milky SMS (29.33 $\times 10^{6} \mathrm{cfu} / \mathrm{g}$ ) which is on par with the same organism on oyster SMS $\left(27.22 \times 10^{6} \mathrm{cfu} / \mathrm{g}\right)$ and the least population of $21.00 \times 10^{6} \mathrm{cfu} / \mathrm{g}$ was observed by Pseudomonas fluorescens on oyster SMS.

\section{At 60 DAI}

After sixty days of inoculation, there was a statistically significant variation between the treatments. Reduction in the population of Pseudomonas fluorescens and Bacillus megaterium continued from thirty to sixty days, in spent mushroom substrates. The population of Trichoderma harzianum has been increased in both talc and different spent mushroom substrates.

Significantly higher population of $88.67 \times 10^{8}$ $\mathrm{cfu} / \mathrm{g}$ was observed in Talc + Pseudomonas fluorescens followed by in $\mathrm{T}_{10}\left(73 \times 10^{8} \mathrm{cfu}\right.$ $/ g)$. Among the different spent mushroom substrates, the maximum population of 41.44 $\times 10^{6} \mathrm{cfu} / \mathrm{g}$ was observed by Trichoderma harzianum on milky SMS followed by the same organism on the oyster SMS (38.44 $\times$ $10^{6} \mathrm{cfu} / \mathrm{g}$ ) and the lowest population was recorded in Pseudomonas fluorescens on oyster SMS $\left(25.22 \times 10^{6} \mathrm{cfu} / \mathrm{g}\right)$ which was on par with the treatment $\mathrm{T}_{5}\left(27.11 \times 10^{6} \mathrm{cfu} / \mathrm{g}\right)$.

Similarly, in consortia also Trichoderma harzianum showed better survivability compared to Pseudomonas fluorescens and Bacillus megaterium. In consortia the highest population was observed with Trichoderma harzianum in Talc $\left(36.00 \times 10^{8} \mathrm{cfu} \mathrm{/g}\right)$ followed by in milky SMS $\left(31.56 \times 10^{6} \mathrm{cfu} / \mathrm{g}\right)$ which was on par with the same on oyster SMS $\left(30.00 \times 10^{6} \mathrm{cfu} / \mathrm{g}\right)$ and least colonies were recorded in Pseudomonas fluorescens $\left(15.55 \times 10^{6} \mathrm{cfu} / \mathrm{g}\right)$ in oyster spent substrates.

Among different spent mushroom substrates, better survivability of plant growth promoting microorganisms was observed in the treatments which received milky spent substrate than oyster mushroom spent substrate.

\section{At 90 DAI}

Survivability of plant growth promoting microorganisms was observed even after ninety days of inoculation though there was drastic reduction in the population was observed at this stage.

At 90 DAI, Trichoderma harzianum survived better compared to Pseudomonas fluorescens and Bacillus megaterium in both consortia and single inoculation on both oyster and milky mushroom spent substrates and it was statistically significant too.

Significantly higher population of $86.00 \times 10^{8}$ cfu /g was observed in Talc $+P$. fluorescens followed by in the treatment (Talc $+B$. megaterium). 


\section{Int.J.Curr.Microbiol.App.Sci (2018) 7(11): 1880-1891}

Table.1 Survivability of plant growth promoting microorganisms on spent mushroom substrate $\left(\times 10^{6} \mathrm{cfu} / \mathrm{g}\right)$

\begin{tabular}{|c|c|c|c|c|c|}
\hline \multicolumn{2}{|c|}{ Treatments } & 30 DAI & 60 DAI & 90 DAI & $120 \mathrm{DAI}$ \\
\hline \multicolumn{2}{|c|}{$\mathrm{T}_{1}-$ Oyster SMS + P. fluorescens } & $52.78^{\mathrm{e}}$ & $25.22^{h}$ & $10.55^{\mathrm{ij}}$ & $2.33^{\mathrm{i}}$ \\
\hline \multicolumn{2}{|c|}{$\mathrm{T}_{2}-$ Oyster SMS + B. megaterium } & $50.11^{\mathrm{f}}$ & $31.11^{\mathrm{g}}$ & $16.22^{h}$ & $5.44^{\mathrm{h}}$ \\
\hline \multicolumn{2}{|c|}{$\mathrm{T}_{3}-$ Oyster SMS + T. harzianum } & $36.89^{g}$ & $38.44^{\mathrm{d}}$ & $25.67^{\mathrm{f}}$ & $11.33^{\mathrm{g}}$ \\
\hline \multirow{3}{*}{$\begin{array}{c}\mathrm{T}_{4}-\text { Oyster SMS + } \\
\text { Consortia }\end{array}$} & P. fluorescens & $21.00^{1}$ & $15.55^{\mathrm{j}}$ & $5.56^{l}$ & $1.44^{\mathrm{i}}$ \\
\hline & B. megaterium & $24.00^{\mathrm{k}}$ & $16.78^{\mathrm{j}}$ & $8.78^{\mathrm{jk}}$ & $2.55^{\mathrm{i}}$ \\
\hline & T. harzianum & $27.22^{\mathrm{j}}$ & $30.00^{\mathrm{g}}$ & $20.11^{\mathrm{g}}$ & $10.22^{\mathrm{g}}$ \\
\hline \multicolumn{2}{|c|}{$\mathrm{T}_{5}-$ Milky SMS + P.fluorescens } & $55.66^{d}$ & $27.11^{\mathrm{h}}$ & $12.22^{\mathrm{i}}$ & $2.00^{\mathrm{i}}$ \\
\hline \multicolumn{2}{|c|}{$\mathrm{T}_{6}-$ Milky SMS + B. megaterium } & $53.44^{\mathrm{e}}$ & $35.00^{f}$ & $17.89^{\mathrm{h}}$ & $4.89^{h}$ \\
\hline \multicolumn{2}{|c|}{ T 7 - Milky SMS + T. harzianum } & $37.67^{\mathrm{g}}$ & $41.44^{\mathrm{d}}$ & $27.56^{\mathrm{e}}$ & $13.22^{f}$ \\
\hline \multirow{3}{*}{$\begin{array}{c}\mathrm{T}_{8}-\text { Milky SMS + } \\
\text { Consortia }\end{array}$} & P. fluorescens & $24.67^{\mathrm{k}}$ & $16.11^{\mathrm{j}}$ & $7.00^{\mathrm{kl}}$ & $1.78^{\mathrm{i}}$ \\
\hline & B. megaterium & $26.00^{\mathrm{jk}}$ & $19.33^{\mathrm{i}}$ & $10.11^{\mathrm{ij}}$ & $2.11^{\mathrm{i}}$ \\
\hline & T. harzianum & $29.33^{1}$ & $31.56^{\mathrm{g}}$ & $21.22^{\mathrm{g}}$ & $11.22^{\mathrm{g}}$ \\
\hline \multicolumn{2}{|c|}{$\mathrm{T}_{9}-\mathrm{Talc}+P$. fluorescens } & $92.00^{\mathrm{a}}$ & $88.67^{\mathrm{a}}$ & $86.00^{\mathrm{a}}$ & $84.00^{\mathrm{a}}$ \\
\hline \multicolumn{2}{|c|}{$\mathrm{T}_{10}-$ Talc + B. megaterium } & $75.00^{b}$ & $73.00^{b}$ & $73.00^{b}$ & $71.67^{b}$ \\
\hline \multicolumn{2}{|c|}{$\mathrm{T}_{11}-$ Talc $+T$. harzianum } & $34.00^{\mathrm{h}}$ & $35.67^{\mathrm{f}}$ & $33.67^{d}$ & $31.33^{e}$ \\
\hline \multirow{3}{*}{$\begin{array}{c}\mathrm{T}_{12}-\text { Talc }+ \\
\text { Consortia }\end{array}$} & P. fluorescens & $75.00^{b}$ & $72.33^{b}$ & $72.33^{b}$ & $69.33^{c}$ \\
\hline & B. megaterium & $66.33^{c}$ & $63.67^{\mathrm{c}}$ & $63.67^{\mathrm{c}}$ & $62.33^{d}$ \\
\hline & T. harzianum & $33.33^{h}$ & $36.00^{f}$ & $33.00^{d}$ & $30.00^{\mathrm{e}}$ \\
\hline
\end{tabular}

Note: Each value represents the mean of 3 replications.

Means with same superscript in column are statistically on par at $\mathrm{P} \leq 0.05$ by DMRT 
Table.2 Survivability of plant growth promoting microorganisms on spent mushroom substrate (Per cent)

\begin{tabular}{|c|c|c|c|c|c|c|}
\hline \multicolumn{2}{|l|}{ Treatments } & 0 DAI & 30 DAI & 60 DAI & 90 DAI & 120 DAI \\
\hline \multicolumn{2}{|c|}{$\mathrm{T}_{1}-$ Oyster SMS + P. fluorescens } & 100 & $60.66^{\mathrm{gh}}$ & $29.00^{\mathrm{k}}$ & $12.133^{i}$ & $2.68^{\mathrm{ef}}$ \\
\hline \multicolumn{2}{|c|}{$\mathrm{T}_{2}-$ Oyster SMS + B. megaterium } & 100 & $66.52^{\text {efgh }}$ & $41.30^{\mathrm{hi}}$ & $21.54^{\mathrm{gh}}$ & $7.23^{\mathrm{ef}}$ \\
\hline \multicolumn{2}{|c|}{$\mathrm{T}_{3}-$ Oyster SMS + T. harzianum } & 100 & $111.54^{\mathrm{bc}}$ & $116.11^{\mathrm{c}}$ & $77.52^{\mathrm{e}}$ & $34.20^{\mathrm{d}}$ \\
\hline \multirow{3}{*}{$\begin{array}{l}\text { T}_{4}-\text { Oyster } \\
\text { SMS + } \\
\text { Consortia }\end{array}$} & P. fluorescens & 100 & $49.85^{\mathrm{i}}$ & $36.9^{\mathrm{ij}}$ & $13.20^{\mathrm{i}}$ & $3.44^{\mathrm{ef}}$ \\
\hline & B. megaterium & 100 & $67.33^{\text {efg }}$ & $48.85^{\mathrm{fg}}$ & $25.61^{\mathrm{fg}}$ & $7.446^{\mathrm{ef}}$ \\
\hline & T. harzianum & 100 & $113.66^{\mathrm{b}}$ & $125.08^{b}$ & $83.84^{\mathrm{cd}}$ & $42.75^{\mathrm{bc}}$ \\
\hline \multicolumn{2}{|c|}{$\mathrm{T}_{5}-$ Milky SMS $+P$. fluorescens } & 100 & $64.38^{\text {tgh }}$ & $31.36^{\mathrm{jk}}$ & $14.13^{\mathrm{i}}$ & $2.31^{\mathrm{f}}$ \\
\hline \multicolumn{2}{|c|}{$\overline{\mathrm{T}_{6}-\text { Milky SMS + B. megaterium }}$} & 100 & $70.49^{\mathrm{ef}}$ & $46.33^{\mathrm{gh}}$ & $23.62^{\text {fg }}$ & $6.50^{\mathrm{ef}}$ \\
\hline \multicolumn{2}{|c|}{$\mathrm{T}_{7}$ - Milky SMS + T. harzianum } & 100 & $116.91^{\mathrm{ab}}$ & $123.25^{b}$ & $81.93^{\mathrm{cd}}$ & $39.29^{c}$ \\
\hline \multirow{3}{*}{$\begin{array}{l}\text { T }_{8}-\text { Milky } \\
\text { SMS + } \\
\text { Consortia }\end{array}$} & P. fluorescens & 100 & $59.85^{\text {gh }}$ & $39.07^{\mathrm{i}}$ & $16.98^{\mathrm{hi}}$ & $4.31^{\text {ef }}$ \\
\hline & B. megaterium & 100 & $72.45^{\mathrm{e}}$ & $53.83^{\mathrm{f}}$ & $28.16^{\mathrm{f}}$ & $5.87^{\mathrm{ef}}$ \\
\hline & T. harzianum & 100 & $122.84^{\mathrm{a}}$ & $132.12^{\mathrm{a}}$ & $88.83^{\mathrm{c}}$ & $46.98^{b}$ \\
\hline \multicolumn{2}{|c|}{$\mathrm{T}_{9}-$ Talc $+P$. fluorescens } & 100 & $101.48^{\mathrm{d}}$ & $100.03^{\mathrm{e}}$ & $97.01^{\mathrm{b}}$ & $94.75^{\mathrm{a}}$ \\
\hline \multicolumn{2}{|c|}{$\mathrm{T}_{10}-$ Talc $+B$. megaterium } & 100 & $102.31^{\mathrm{d}}$ & $99.56^{\mathrm{e}}$ & $99.56^{\mathrm{ab}}$ & $97.74^{\mathrm{a}}$ \\
\hline \multicolumn{2}{|c|}{$\mathrm{T}_{11}-$ Talc $+T$. harzianum } & 100 & $102.23^{\mathrm{d}}$ & $107.33^{\mathrm{d}}$ & $101.37^{\mathrm{ab}}$ & $94.29^{\mathrm{a}}$ \\
\hline \multirow{3}{*}{$\begin{array}{l}T_{12}-\text { Talc }+ \\
\text { Consortia }\end{array}$} & P. fluorescens & 100 & $101.37^{\mathrm{d}}$ & $97.82^{\mathrm{e}}$ & $97.82^{b}$ & $93.75^{\mathrm{a}}$ \\
\hline & B. megaterium & 100 & $101.03^{\mathrm{d}}$ & $96.98^{\mathrm{e}}$ & $96.98^{b}$ & $95.02^{\mathrm{a}}$ \\
\hline & T. harzianum & 100 & $105.37^{\mathrm{cd}}$ & $113.65^{\mathrm{c}}$ & $104.43^{\mathrm{a}}$ & $94.75^{\mathrm{a}}$ \\
\hline
\end{tabular}

Note: Each value represents the mean of 3 replications.

Means with same superscript in column are statistically on par at $\mathrm{P} \leq 0.05$ by DMRT 
Int.J.Curr.Microbiol.App.Sci (2018) 7(11): 1880-1891

Fig.1a Survivability of Pseudomonas fluorescens on spent mushroom substrate

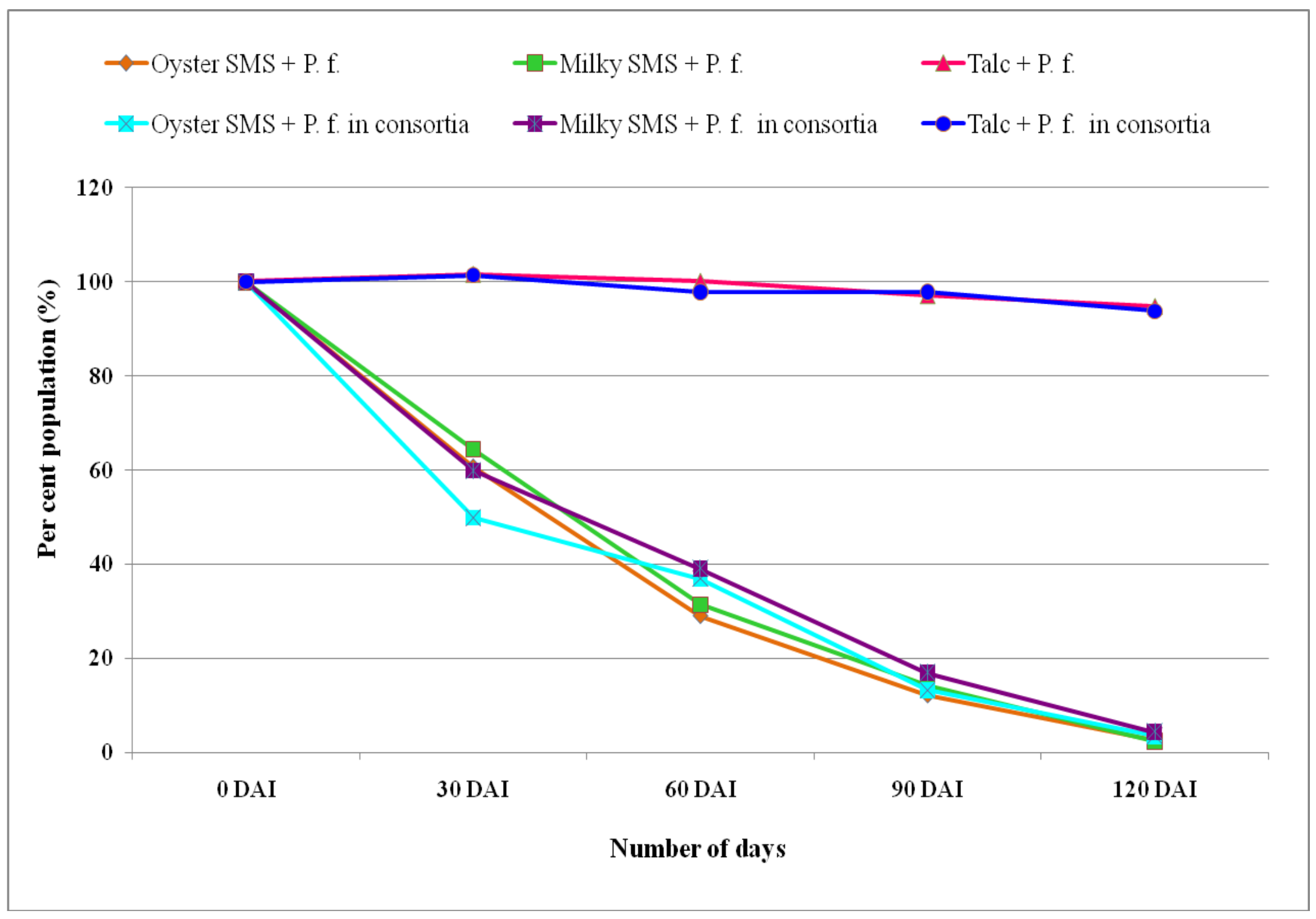


Int.J.Curr.Microbiol.App.Sci (2018) 7(11): 1880-1891

Fig.1b Survivability of Bacillus megaterium on spent mushroom substrate

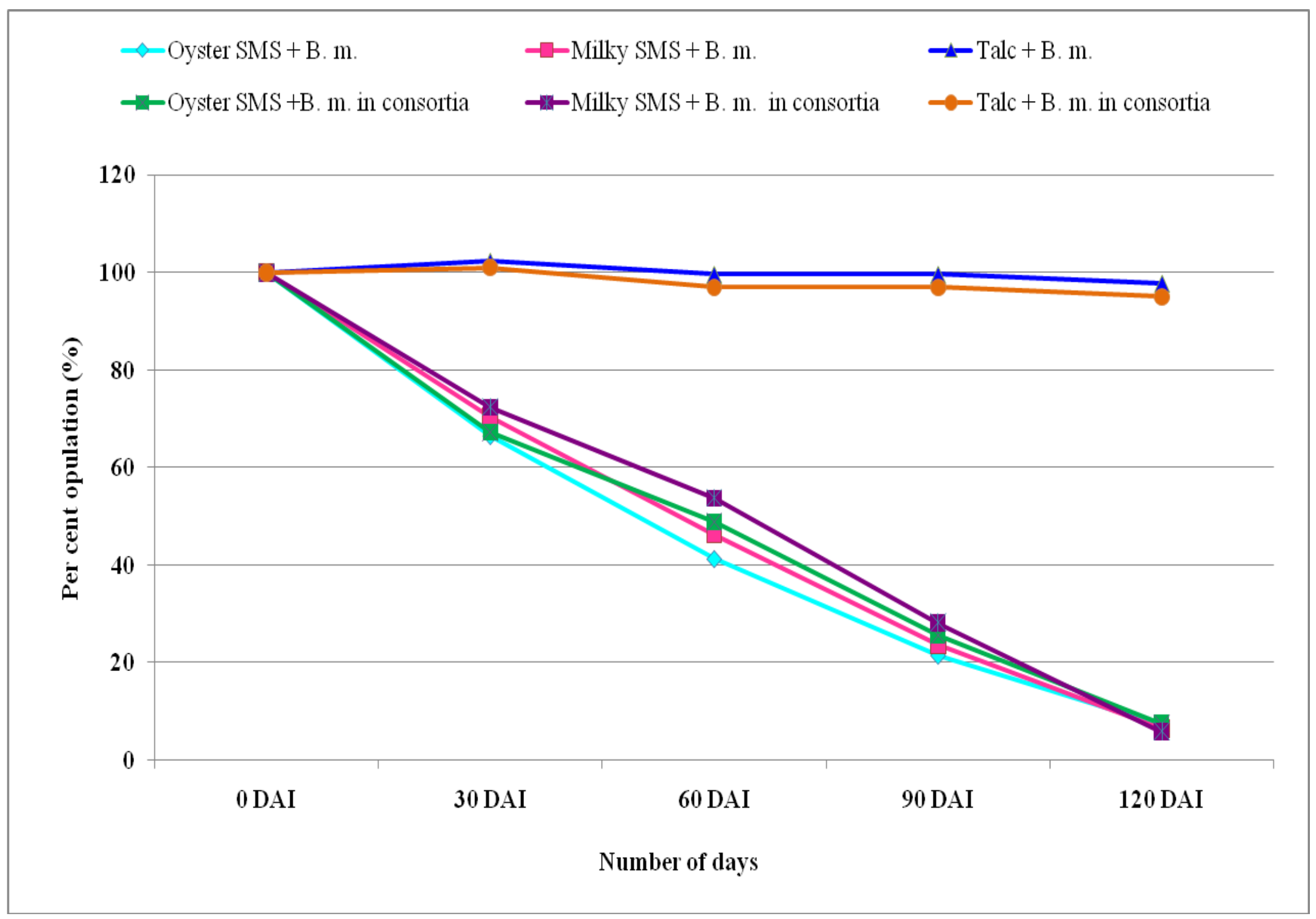


Fig.1c Survivability of Trichoderma harzianum on spent mushroom substrate

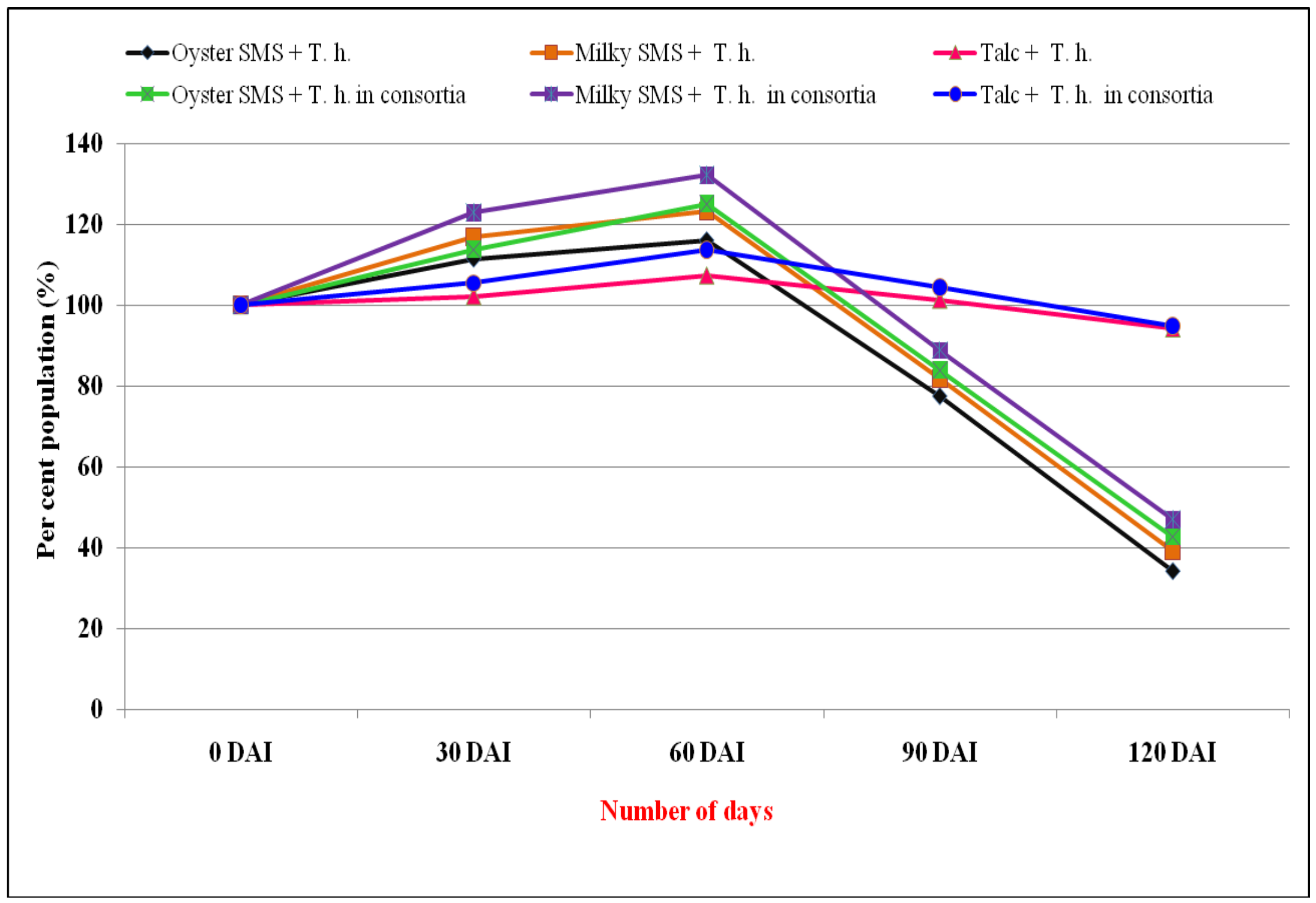




\section{Initial chemical properties of substrates}

\begin{tabular}{|l|c|c|c|c|c|c|c|}
\multicolumn{1}{|c|}{ Sulbstrates } & pH & $\begin{array}{c}\text { EC } \\
\left(\mathbf{d S m}^{-1}\right)\end{array}$ & $\begin{array}{c}\text { OC } \\
(\%)\end{array}$ & $\begin{array}{c}\text { N } \\
(\%)\end{array}$ & P (\%) & K (\%) & $\begin{array}{c}\text { C: N } \\
\text { Ratio }\end{array}$ \\
\hline Paddy straw & 7.23 & 0.65 & 45.50 & 0.85 & 0.42 & 1.06 & 53.53 \\
\hline Sugarcane trash & 6.85 & 0.58 & 68.54 & 0.62 & 0.22 & 0.42 & 110.55 \\
\hline $\begin{array}{l}\text { Paddy straw + } \\
\text { Sugarcane trash (1:1) }\end{array}$ & 6.93 & 0.61 & 56.45 & 0.74 & 0.37 & 0.93 & 76.28 \\
\hline
\end{tabular}

Among the treatments treated with spent mushroom spent mushroom, maximum population $\left(27.56 \times 10^{6} \mathrm{cfu} / \mathrm{g}\right)$ was observed in Trichoderma harzianum on milky mushroom spent substrate followed by the same organism on oyster spent substrate $\left(25.67 \times 10^{6} \mathrm{cfu} / \mathrm{g}\right)$ and minimum colonies were observed in Pseudomonas fluorescens on oyster mushroom spent substrate. In consortia also more population of $33.00 \times 10^{8}$ $\mathrm{cfu} / \mathrm{g}$ was recorded by Trichoderma harzianum in talc carrier material followed by in both milky $\left(21.22 \times 10^{6} \mathrm{cfu} / \mathrm{g}\right)$ and oyster $\left(20.11 \times 10^{6} \mathrm{cfu} / \mathrm{g}\right)$ mushroom spent substrate and they were on par with each other. Significantly least population of $5.56 \times 10^{6} \mathrm{cfu}$ /g was observed in Pseudomonas fluorescens on oyster mushroom spent substrate.

As noticed in 30, 60 and 90 DAI, among different spent mushroom substrates used, survival of plant growth promoting microorganisms was better in milky mushroom spent substrate than oyster mushroom spent mushroom substrate.

\section{At 120 DAI}

At 120 DAI, decline in population of plant growth promoting microorganisms was observed and it varied significantly among the treatments. At this stage population of Pseudomonas fluorescens and Bacillus megaterium was very less in both oyster and milky mushroom spent substrate, but Trichoderma harzianum showed good survivability even at 120 DAI. However, best survivability plant growth promoting microorganisms (Pseudomonas fluorescens, Bacillus megaterium and Trichoderma harzianum) was observed in treatments which received talc as carrier material.

Significantly maximum population of 84.00 $\times 10^{8} \mathrm{cfu} / \mathrm{g}$ was found in the treatment $\mathrm{T}_{9}$ (Talc + P. fluorescens) followed by in $\mathrm{T}_{10}$ $\left(73.00 \times 10^{8} \mathrm{cfu} / \mathrm{g}\right)$ i.e., treated with Talc + Bacillus megaterium. Among the treatments which received spent mushroom substrate, Trichoderma harzianum recorded significantly the highest population of 13.22 $\times 10^{6} \mathrm{cfu} / \mathrm{g}$ on milky spent mushroom substrate followed by the population of same organism on oyster spent mushroom substrate $\left(11.33 \times 10^{6} \mathrm{cfu} / \mathrm{g}\right)$. Slimilarly in consortia, the maximum population $\left(69.33 \times 10^{8} \mathrm{cfu} / \mathrm{g}\right)$ was observed by $P$. fluorescens in Talc and the least population was observed with Pseudomonas fluorescens in consortia of both milky and oyster spent mushroom substrates $\left(1.44 \times 10^{6} \mathrm{cfu} / \mathrm{g}\right.$ and $1.77 \times 10^{6} \mathrm{cfu} / \mathrm{g}$ respectively) and they were on par with each other.

At all the intervals of population studied, treatments which received inoculation of single organism showed higher population compared to population in consortia which contains all three plant growth promoting microorganisms (Pseudomonas fluorescens + Bacillus megaterium + Trichoderma harzianum). Pseudomonas fluorescens showed maximum population at initial stage and reduced continuously at 30,60 and 90 
days of inoculation in spent mushroom substrate. Similar trend was observed in Bacillus megaterium but population was more compared to Pseudomonas fluorescens.

In case of Trichoderma harzianum though initial population was less, at 30 DAI slight improvements was observed. Similarly at 60 DAI, increase in population was recorded in both milky and oyster spent substrates. The population of Trichoderma harzianum started decreasing after 90 DAI and reduction in population continued even at 120 DAI. Significantly very less population of all the plant growth promoting microorganisms was observed in 120 DAI, but they survived up to 120 days on both milky and oyster spent substrates. Though survivability of Pseudomonas fluorescens and Bacillus megaterium was best in talc carrier material, Trichoderma harzianum survived better in both Talc and spent mushroom substrate.

From the results of survivability studies it is confirmed that, spent mushroom substrate can be used as carrier material for inoculation of plant growth promoting microorganisms. Among different plant growth promoting microorganisms, Trichoderma harzianum showed better survivability. This may be due to the fact that nutrient content present in spent mushroom substrate supported the survival of microbial inoculants during the storage period. Dinesh et al., (2000) observed that the spent mushroom substrate acts as an organic manure rich in nutrients will enhance the microbial activity.

The obtained results are in confirmation with the results of Dayananda (2008). He observed a similar trend of survivability of beneficial microorganisms in raw coir pith as well as in milky mushroom spent coir pith. Higher survivability of beneficial microorganisms was observed in milky mushroom spent coir pith compared to raw coir pith.
Sharma and Kumar (2011) also reported that spent mushroom compost (SMC) favored good growth of Trichoderma harzianum. The population $T$. harzianum was in the range of $10^{4} / \mathrm{g}$ substrate at starting (0 day) and then it reached $8.72 \times 10^{6} / \mathrm{g}$ substrate at the end of fourth week indicating better growth and sporulation of $T$. harzianum in spent mushroom compost. The spent mushroom compost of many mushroom species has been reported to favour survivability of Trichoderma spp.

Similarly, Yohalem et al., (1996) reported that spent mushroom substrates maintains higher population of PGPR even after one month that resulted in less scab affected leaf area in SMS sprayed treatment. SMS compost inoculated with $P$. farinose FL7 might be a good strategy for biofertilizer preparation. Conversion of SMS for biofertilizer production using a stress-tolerant phosphate solubilizing microorganism $P$. farinose FL7 demonstrated the tremendous potential for the reuse of locally available agricultural waste material (Zhu et al., 2012). In consortia, all the microorganisms grew without suppressing each other indicating synergistic interaction during their growth, similar results were reported by Anandaraj and Delapierre (2010) and Belkar and Gade (2012).

\section{References}

Anandaraj, B. and Delapierre, L. R. A., 2010, Studies on influence of bioinoculants (Pseudomonas fluorescens, Rhizobium sp., Bacillus megaterium) in green gram. J. Biosci. Tech., 1: 95-99.

Bandara, A. R., Rapiord, S., Bhat, D. J., Kakumyana, P., Chamyuang, S., Jianchu, X. U. and Kevin, D. H., 2015, Polyporus umbellatus, an ediblemedicinal cultivated mushroom with multiple developed health-care products as food, medicine and cosmetics: a 
review. Cryptogamie Mycologie, 36(1): 3-42.

Belkar, Y. K. and Gade, R. M., 2012, Compatibility of fluorescent pseudomonads with beneficial microorganisms. J. Plant Dis. Sci., 7: $269-270$.

Chandulal, K., Gopal, C. and John, P., 2013, Studies on biodiversity of fleshy fungi in Navsari (South Gujarat), India. Int. J. Biodiv. Conser., 5(8): 508-514.

Chorover, R. H., Fox Hatcher, C. P. and Romaine., 2000, Final Research Project Report - Mushroom Industry Farmerbased Applied Research Program (MIFBAR) (The Pennsylvania State University). p. 87.

Jackson, M. L., 1973, Soil Chemical Analysis, Prentice Hall of India Pvt. Ltd., New Delhi. pp. 485-498.

Mikhailova, E. A., Noble, R. R. P. and Post, C. J., 2003, Comparison of soil organic carbon recovery by Walkley-Black and dry combustion methods in the Russian Chernozem. Commu. Soil Sci. Plant Ana., 34: 1853-1860.

Mortimer, P. E., Karunarathna, S. C., Li, Q. H., Gui, H., Yang, X. Q., Yang, X. F., He, J., Ye, L., Guo, J. Y., Li, H. L., Sysouphanthong, P., Zhou, D. Q. and Hyde, K. D., 2012, Prized edible Asian mushrooms: ecology, conservation and sustainability. Fungal Diversity, 56 (1): 31-47.
Piper, C. S., 1966, Soil and Plant Analysis, Surabhi Publication, New Delhi.

Robbins, S. H., Reghetti, T. L., Fallahi, E., Dixon, A. R., Chaplin, M. H., 1986, Commu. Soil Sci. Plant Ana., 17: 457471.

Sharma, S. K. and Atri, N. S., 2014, Nutraceutical composition of wild species of genus Lentinus Fr. From Nothern India. Curr. Res. Environ. Appl. Mycol., 4 (1): 11-32.

Sharma, V. P. and Kumar, S., 2011, Competitor moulds and diseases in Mushroom production and their management. In: Mushrooms: Cultivation, Marketing and Consumption (Manjit Singh, Bhuvnesh Vijay, Shwet Kamal and GC Wakchaure eds.). Directorate of Mushroom Research, Solan, India. pp. $155-174$.

Yohalem, D. S., Nordheim, E. V. and Andrews, J. H., 1996, The effect of water extracts of spent mushroom compost on apple scab in the field. Phytopathol., 86(9): 914-922.

Zhu, H. J., Sun, L. F., Zhang, Y. F., Zhang, X. L. and Qiao, J. J., 2012, Conversion of spent mushroom substrate to biofertilizer using a stress-tolerant phosphate-solubilizing Pichia farinose FL7. Biores. Technol., 111: 410-416.

\section{How to cite this article:}

Dakshayini, G. and Mallesha, B.C. 2018. Survivability of Plant Growth-Promoting Microorganisms on Spent Mushroom Substrate. Int.J.Curr.Microbiol.App.Sci. 7(11): 18801891. doi: https://doi.org/10.20546/ijcmas.2018.711.213 